\title{
Keefektifan Perlakuan Panas Kering dan Iradiasi UV-C untuk Mematikan Cendawan Model Microcyclus ulei
}

\author{
The Effectiveness of Dry Heat Treatment and UV-C Irradiation \\ to Kill The Fungus Models of Microcyclus ulei \\ Aprida Cristin ${ }^{1,2}$, Meity Suradji Sinaga ${ }^{1 *}$, Abdul Muin Adnan ${ }^{1}$ \\ ${ }^{1}$ Institut Pertanian Bogor, Bogor 16680 \\ ${ }^{2}$ Badan Karantina Pertanian, Jakarta 12550
}

\begin{abstract}
ABSTRAK
Studi dilakukan untuk mengembangkan metode perlakuan serta menentukan dosis efektif perlakuan panas kering dan iradiasi UV-C yang dapat mematikan cendawan model Microcyclus ulei pada biji dan bungkil kedelai tanpa merusak kandungan nutrisinya. Cendawan model yang digunakan ialah Colletotrichum gloeosporioides, Botryodiplodia theobromae, Fusarium oxysporum f. sp. niveum, dan Sclerotium rolfsii. Perlakuan iradiasi UV-C pada jarak 15 dan $30 \mathrm{~cm}$ dari lampu UV-C dengan waktu dedah 12 dan 24 jam tidak efektif membunuh biakan semua cendawan model uji di medium PDA. Perlakuan panas kering pada suhu $55^{\circ} \mathrm{C}$ selama 30 dan 60 menit efektif mematikan biakan $C$. gloeosporioides, B. theobromae, dan S. rolfsii pada medium PDA, kecuali F. oxysporum f. sp. niveum. Pengujian pada kedelai menunjukkan bahwa perlakuan suhu $55^{\circ} \mathrm{C}$ selama 30 menit efektif mematikan konidia $C$. gloeosporioides, $B$. theobromae, dan F. oxysporum $\mathrm{f}$. sp. niveum, tanpa merusak kandungan protein total kedelai, tetapi perlakuan panas kering pada suhu $60{ }^{\circ} \mathrm{C}$ selama 60 menit tidak efektif mematikan sklerotia $S$. rolfsii. Apabila sifat tahan M. ulei menyerupai S. rolfsii, akan diperlukan suhu dan waktu perlakuan panas yang lebih tinggi daripada yang dilakukan dalam pengujian ini.

Kata kunci: Botryodiplodia theobromae, bungkil kedelai, dosis efektif, Colletotrichum gloeosporioides, Fusarium oxysporum f. sp. niveum, Sclerotium rolfsii
\end{abstract}

\begin{abstract}
This study was carried out to develop treatment methods and determine the effective dose of dry heat treatment and UV-C irradiation to kill the fungus models of Microcyclus ulei on soybean grains and soybean meals without damaging its nutritional content. The fungus models used in this study were Colletotrichum gloeosporioides, Botryodiplodia theobromae, Fusarium oxysporum f. sp. niveum, and Sclerotium rolfsii. The results showed that UV-C treatment up to 12 and 24 hours exposure time at 15 and $30 \mathrm{~cm}$ from UV-C light was not effective to kill all fungus models in PDA. Dry heat treatment at $55^{\circ} \mathrm{C}$ for 30 and 60 minutes was effective to kill cultures of $C$. gloeosporioides, B. theobromae, and $S$. rolfsii in PDA, except for $F$. oxysporum $\mathrm{f}$. sp. niveum. Further experiments on soybean showed that dry heat treatment at $55^{\circ} \mathrm{C}$ for 30 minutes was effective to kill conidia of $C$. gloeosporioides, $B$. theobromae, and $F$. oxysporum f. sp. niveum, without damaging its protein content. However, dry heat treatment at $60{ }^{\circ} \mathrm{C}$ for 60 minutes has been proved not effective to kill sclerotia of $S$. rolfsii. If $M$. ulei had the similar resistance as $S$. rolfsii, then it would need a higher temperature and time than used in this study to kill the fungus.
\end{abstract}

Key words: Botryodiplodia theobromae, Colletotrichum gloeosporioides, effective doses, Fusarium oxysporum f. sp. niveum, Sclerotium rolfsii, soybean meals

*Alamat penulis korespondensi: Departemen Proteksi Tanaman, Fakultas Pertanian, Institut Pertanian Bogor,

Kampus Darmaga, Jalan Kamper, Bogor 16680

Tel: 0251-8629364, Faks:0251-8629362, Surel: mssinaga@yahoo.com 


\section{PENDAHULUAN}

Microcyclus ulei penyebab penyakit hawar daun karet Amerika Selatan (SALB) merupakan faktor utama yang menghambat perkembangan industri karet alam di Amerika Selatan dan menjadi ancaman bagi negaranegara penghasil karet alam di Asia Pasifik, termasuk Indonesia (Edathil 1986). Askospora dan konidium $M$. ulei diketahui mampu bertahan hidup pada kondisi ekstrem dan dalam waktu yang cukup lama, baik pada komoditas pertanian maupun material lainnya. Konidium M. ulei yang diletakkan pada kaca objek dan disimpan dalam desikator selama 16 minggu masih mampu berkecambah, sementara askospora yang disimpan dalam desikator juga masih mampu bertahan hidup selama 15 hari (Chee 1976). Selain itu, konidium M. ulei yang disimpan selama 7 hari pada kertas, kaca, plastik, kulit sintetis, pakaian, besi, tanah kering dan tanah basah juga masih mampu berkecambah sebesar 5.831.6\% (Hashim 2007).

Pencegahan penyebaran M. ulei ke Asia Pasifik terus dilakukan oleh negara-negara penghasil karet alam yang tergabung dalam Asia Pacific Plant Protection Commission (APPPC) dengan menetapkan patogen ini sebagai organisme pengganggu tumbuhan karantina (OPTK) yang dilarang pemasukannya ke Asia Pasifik (FAO 2007). Secara khusus, Indonesia menetapkan M. ulei sebagai OPTK A1, yaitu OPTK yang belum terdapat di Indonesia dan dilarang pemasukannya ke dalam wilayah Republik Indonesia (RI) (Kementan 2011). Apabila M. ulei berhasil masuk ke Indonesia, masih berisiko tinggi untuk tersebar dan berkembang di wilayah pertanaman karet di Indonesia, mengingat ekosistem asli M. ulei di Amerika Selatan, khususnya Brazil sama dengan Indonesia.

Selama ini, pencegahan masuknya M. ulei ke wilayah RI telah dilakukan melalui implementasi Keputusan Menteri Pertanian (Kepmentan) Nomor 861/Kpts/ LB.720/12/1989 tentang pencegahan masuknya penyakit hawar daun hevea Amerika Selatan ke dalam wilayah negara Republik
Indonesia (Deptan 1989), antara lain dengan perlakuan karantina iradiasi sinar ultraviolet (253-257 nm) selama 15 menit atau perlakuan uap panas $55{ }^{\circ} \mathrm{C}$ selama 30 menit terhadap pemasukan hasil tanaman berupa bahan tanaman mati yang berasal dari negara endemis SALB. Namun, hasil penelitian terakhir menunjukkan bahwa konidium M. ulei mati dengan perlakuan iradiasi sinar UV-C selama 60 menit (Juri et al. 1997) atau dengan perlakuan panas kering pada suhu $55{ }^{\circ} \mathrm{C}$ selama 30 menit (Hashim 2007). Oleh karena itu, perlakuan dalam lampiran Kepmentan No. 861/1989 perlu ditinjau kembali, terutama ketika $M$. ulei menjadi kontaminan pada komoditas kedelai asal Brazil, khususnya bungkil kedelai karena menurut data e-plaq Badan Karantina Pertanian, 99\% kedelai Brazil yang masuk ke Indonesia pada tahun 2010-2011 ialah dalam bentuk bungkil sebagai pakan ternak.

Penelitian bertujuan mengembangkan metode perlakuan, menentukan dosis iradiasi dan suhu pemanasan yang efektif mematikan cendawan model M. ulei pada biji dan bungkil kedelai tanpa merusak kandungan total protein. Status M. ulei sebagai OPTK A1, sehingga digunakan cendawan model yang sudah ada di Indonesia dengan karakteristik bertahan pada kondisi ekstrem mirip M. ulei. Cendawan Colletotrichum gloeosporioides, Botryodiplodia theobromae, dan Fusarium oxysporum f. sp. niveum dipilih karena memiliki teleomorf dengan filum yang sama dengan $M$. ulei atau dari kelas lainnya, seperti Sclerotium rolfsii yang membentuk sklerotium sebagai struktur bertahan.

\section{BAHAN DAN METODE}

Komoditas uji yang digunakan adalah biji kedelai konsumsi asal Amerika Serikat dan bungkil kedelai asal Brazil. Isolat murni cendawan model bagi struktur konidium $M$. ulei ialah $B$. theobromae (isolasi dari jeruk, asal Garut, koleksi Laboratorium Mikologi, Departemen Proteksi Tanaman IPB), $C$. gloeosporioides (isolasi dari cabai, asal Bandung, koleksi Laboratorium Fitopatologi, 
Fakultas Pertanian, Universitas Padjajaran), dan $F$. oxysporum f. sp. niveum (isolasi dari semangka, asal Karawang, koleksi Laboratorium Mikologi, Departemen Proteksi Tanaman IPB). Sebagai model struktur bertahan $M$. ulei pada kondisi ekstrem digunakan isolat murni cendawan $S$. rolfsii (isolasi dari sengon, asal Bandung, koleksi Laboratorium Fitopatologi, Fakultas Pertanian Universitas Padjajaran) yang membentuk sklerotia. Alat untuk perlakuan panas kering ialah oven (merk Memert) yang telah dikalibrasi, sedangkan alat perlakuan iradiasi UV-C adalah alumunium chamber berukuran $118 \mathrm{~cm} \times 59 \mathrm{~cm} \times 48 \mathrm{~cm}$ dan sebuah lampu dengan spesifikasi UV-C dengan daya 36 Watt.

\section{Perlakuan Iradiasi UV-C terhadap Pertumbuhan Koloni Cendawan Model}

Pengujian dilakukan untuk memberikan gambaran waktu dan jarak dedah perlakuan iradiasi UV-C yang efektif mematikan cendawan model. Pengujian disusun dengan rancangan acak lengkap (RAL) dengan tiga ulangan. Perlakuan diberikan pada semua biakan cendawan model berumur 7 hari selama 0 (kontrol), 30, 60, 90, dan 120 menit pada jarak $40 \mathrm{~cm}$ dari lampu UV-C. Penutup cawan petri diganti dengan pembungkus plastik (plastic film) untuk menghindari kontaminasi dan memaksimalkan penetrasi sinar UV-C pada cendawan model. Setelah perlakuan, biakan segera ditumbuhkan pada medium PDA dengan memindahkan potongan biakan (diameter $3 \mathrm{~mm}$ ) dari tiga sisi (kanan, tengah, kiri) dan diinkubasi selama 3 hari pada suhu ruang. Sklerotium $S$. rolfsii sebagai inokulum awal saat peremajaan ikut ditumbuhkan pada cawan petri yang sama dengan miseliumnya. Peubah yang diamati ialah diameter koloni cendawan model. Penghambatan relatif perlakuan (PHR) terhadap kontrol dihitung dengan rumus Abbott (Kaiser et al. 2005):

$$
\mathrm{PHR}=\frac{\mathrm{dk}-\mathrm{dp}}{\mathrm{dk}} \times 100 \%, \text { dengan }
$$

$\mathrm{dk}$, diameter koloni cendawan model tanpa perlakuan (kontrol); dp, diameter koloni cendawan model yang diberi perlakuan.
Pengujian dilanjutkan dengan menambahkan waktu dedah UV-C menjadi 3, 5, 7, dan 9 jam pada jarak $30 \mathrm{~cm}$ karena pengujian awal belum berhasil mematikan cendawan model. Namun, karena hasilnya masih sama, pengujian dilanjutkan lagi dengan menambahkan waktu dedah hingga 12 dan 24 jam pada jarak 15 dan $30 \mathrm{~cm}$. Dalam pengujian ini digunakan RAL faktorial $2 \times 3$ dengan tiga ulangan, dimana jarak serta waktu dedah digunakan sebagai faktornya. Selanjutnya, dilakukan pemeriksaan panjang gelombang lampu UV-C di Laboratorium Spektroskopi, Departemen Fisika, IPB.

\section{Perlakuan Panas Kering terhadap Pertumbuhan Koloni Cendawan Model}

Pengujian dilakukan untuk memberikan gambaran suhu dan waktu perlakuan yang efektif untuk mematikan cendawan model. Pengujian menggunakan RAL faktorial $3 \times 5$ dengan tiga ulangan. Faktor pertama adalah waktu: 0 (kontrol), 30, dan 60 menit; sedangkan faktor kedua adalah suhu: 45, 50, 55, 60, dan $65{ }^{\circ} \mathrm{C}$. Perlakuan diberikan pada semua biakan cendawan model berumur 7 hari. Biakan yang telah diberi perlakuan segera ditumbuhkan pada medium PDA dengan cara dan tahapan yang sama pada perlakuan iradiasi UV-C. Peubah yang diamati ialah diameter koloni dan PHR dihitung dengan rumus yang sama pada perlakuan iradiasi UV-C.

\section{Perlakuan Panas Kering terhadap Daya Tumbuh Cendawan Model pada Biji dan Bungkil Kedelai}

Pengujian dilakukan untuk mengetahui suhu dan waktu perlakuan yang efektif untuk mematikan cendawan model pada biji dan bungkil kedelai. Pengujian menggunakan RAL faktorial $3 \times 3$ dengan lima ulangan. Dosis perlakuan panas kering (suhu dan waktu) yang efektif mematikan cendawan model pada pengujian di potato dextrose agar (PDA) digunakan sebagai faktornya, yaitu suhu 50,55 , dan $60{ }^{\circ} \mathrm{C}$ selama 0 (kontrol), 30, dan 60 menit. Percobaan diawali dengan inokulasi buatan cendawan model pada biji dan bungkil kedelai yang akan diberi perlakuan maupun tanpa perlakuan (kontrol). 
Inokulasi C. gloeosporioides, B. theobromae, dan $F$. oxysporum f. sp. niveum dilakukan dengan menambahkan suspensi inokulum (massa konidium) ke dalam cawan petri yang berisi 80 biji kedelai atau 5 g bungkil kedelai. Inokulum yang ditambahkan pada biji sebanyak $2 \mathrm{~mL}$ dengan kepadatan $\pm 10^{2} \mathrm{cfu} \mathrm{mL}^{-1}$, sedangkan pada bungkil ialah $4 \mathrm{~mL}$ dengan kepadatan $\pm 10^{3}$ cfu $\mathrm{mL}^{-1}$. Inokulasi $S$. rolfsii dilakukan dengan menambahkan 4 sklerotium berumur sekitar 3 minggu pada biji atau bungkil kedelai. Biji dan bungkil kedelai yang telah diinokulasi diberi perlakuan panas kering maupun tanpa perlakuan (kontrol) kemudian dicuci dengan $10 \mathrm{~mL}$ akuades steril. Sebanyak $1 \mathrm{~mL}$ cairan hasil pencucian tersebut diinokulasikan ke medium PDA kemudian diinkubasi selama 3-5 hari. Pencucian bungkil dilakukan dengan bantuan vortex pada kecepatan 2500 rpm selama 30 detik, sedangkan pencucian biji dilakukan dengan menggoyangkan cawan petri secukupnya. Biji dan bungkil yang diinokulasi dengan sklerotium tanpa pencucian, tetapi sklerotium langsung dipindahkan ke medium PDA dan diinkubasi selama 3-5 hari. Pengamatan dilakukan terhadap jumlah koloni cendawan model yang tumbuh pada medium PDA.

\section{Dampak Perlakuan Panas Kering terhadap Kandungan Protein pada Biji dan Bungkil Kedelai}

Analisis kandungan protein dilakukan terhadap biji dan bungkil kedelai yang diinokulasi C. gloeosporioides - cendawan ini bersifat seed borne dan seed transmitted yang sering menyebabkan benih gagal tumbuh-baik yang diberi perlakuan maupun tanpa perlakuan (kontrol), tanpa pencucian. Sebagai pembanding, analisis dilakukan juga pada biji dan bungkil tanpa inokulasi, tetapi hanya ditambahkan air steril, baik yang diberi perlakuan maupun tanpa perlakuan (kontrol), dan tanpa pencucian. Analisis protein dilakukan di Laboratorium Pengujian Balai Besar Penelitian dan Pengembangan Pascapanen Pertanian, Bogor.

\section{Analisis Data}

Data hasil pengujian perlakuan iradiasi UV-C dan panas kering dianalisis dengan sidik ragam (analysis of variance), dilanjutkan dengan uji Tukey pada taraf nyata $1 \%$ untuk memperoleh metode dan dosis perlakuan yang efektif mematikan cendawan model $(\mathrm{PHR}=100 \%)$, menggunakan Program Minitab 16. Data PHR pertumbuhan cendawan model M. ulei (Tabel 4) dianalisis dengan Program Polo Plus Versi 1.0.

\section{HASIL}

\section{Perlakuan Iradiasi UV-C terhadap Pertumbuhan Koloni Cendawan Model}

Perlakuan iradiasi UV-C pada koloni cendawan model selama 0 (kontrol), 30, 60, 90, dan 120 menit pada jarak $40 \mathrm{~cm}$ dari lampu UV-C tidak dapat mematikan cendawan model. Walaupun terjadi penghambatan pertumbuhan koloni, namun secara umum waktu iradiasi sinar UV-C tidak berpengaruh (Tabel 1). Hal serupa juga terjadi setelah dilakukannya penambahan waktu dedah UV-C menjadi 3, 5, 7, 9, 12, dan 24 jam pada jarak $30 \mathrm{~cm}$ (Tabel 2).

Tabel 1 Penghambatan relatif (PHR) pertumbuhan cendawan model Microcyclus ulei setelah perlakuan iradiasi UV-C dengan jarak $40 \mathrm{~cm}$ pada berbagai waktu dedah

\begin{tabular}{lcccrr}
\hline \multirow{2}{*}{ Biakan cendawan model } & \multicolumn{6}{c}{ PHR (\%) berdasarkan waktu dedah (menit)* } \\
\cline { 2 - 6 } & 0 & 30 & 60 & 90 & 120 \\
\hline Colletotrichum gloeosporioides & $0 \mathrm{a}$ & $1 \mathrm{a}$ & $5 \mathrm{a}$ & $7 \mathrm{a}$ & $12 \mathrm{a}$ \\
Botryodiplodia theobromae & $0 \mathrm{a}$ & $0 \mathrm{a}$ & $9 \mathrm{a}$ & $13 \mathrm{a}$ & $2 \mathrm{a}$ \\
Fusarium oxysporum f. sp. niveum & $0 \mathrm{a}$ & $5 \mathrm{a}$ & $1 \mathrm{a}$ & $4 \mathrm{a}$ & $11 \mathrm{a}$ \\
Miselium Sclerotium rolfsii & $0 \mathrm{c}$ & $2 \mathrm{bc}$ & $66 \mathrm{abc}$ & $85 \mathrm{a}$ & $78 \mathrm{ab}$ \\
Sklerotium S. rolfsii & $0 \mathrm{a}$ & $-12 \mathrm{ab}$ & $-33 \mathrm{abc}$ & $-62 \mathrm{c}$ & $-54 \mathrm{bc}$ \\
\hline
\end{tabular}

*Angka-angka pada baris yang sama yang diikuti oleh huruf yang sama tidak berbeda nyata berdasarkan uji

Tukey pada taraf nyata $1 \%$.

-, tidak terjadi penghambatan relatif pada cendawan model setelah mendapat perlakuan 
Perlakuan iradiasi UV-C selama 24 jam pada jarak $15 \mathrm{~cm}$ tetap tidak memberikan pengaruh mematikan pada cendawan model, tetapi hanya menghambat pertumbuhan koloni dengan nilai penghambatan relatif perlakuan pada waktu dedah 12 jam cenderung lebih besar dibandingkan dengan 24 jam untuk jarak yang sama (Tabel 3).

Pemeriksaan panjang gelombang lampu UV-C menunjukkan lampu memiliki panjang gelombang antara 200-800 nm sehingga sinar yang dipancarkan tidak murni pada panjang gelombang UV-C (200-280 nm). Hasil pemeriksaan menunjukkan lampu memiliki panjang gelombang UV-A atau NUV (315-400 nm), UV-B (280-315 nm), dan cahaya tampak (400-780 nm). Namun demikian, intensitas tertinggi tetap didominasi oleh panjang gelombang 200-280 nm (UV-C) (Gambar 1).

\section{Perlakuan Panas Kering terhadap} Pertumbuhan Koloni Cendawan Model

Hasil perlakuan panas kering pada koloni cendawan model menunjukkan suhu $55{ }^{\circ} \mathrm{C}$ selama 30 dan 60 menit dapat mematikan C. gloeosporioides, B. theobromae, dan $S$. rolfsii, sementara pada $F$. oxysporum f. sp. niveum hanya menunjukkan penghambatan relatif pertumbuhan koloni sebesar 38\% dan 42\% (Tabel 4). Semakin lama waktu perlakuan relatif menyebabkan peningkatan penghambatan pertumbuhan koloni cendawan model M. ulei. Secara umum, hasil analisis data PHR pertumbuhan cendawan model M. ulei (Tabel 4) dengan Program Polo Plus Versi 1.0 lebih sesuai dengan data aktual pengujian perlakuan panas kering, karena $\mathrm{LD}_{99}$ terjadi pada suhu yang sedikit lebih

Tabel 2 Penghambatan relatif (PHR) pertumbuhan cendawan model Microcyclus ulei setelah perlakuan iradiasi UV-C dengan jarak $30 \mathrm{~cm}$ pada berbagai waktu dedah

\begin{tabular}{llcccccc}
\hline \multirow{2}{*}{ Biakan cendawan model } & \multicolumn{7}{c}{ PHR (\%) } \\
\cline { 2 - 8 } & 0 & 3 & 5 & 7 & 9 & 12 & 24 \\
\hline Colletotrichum gloeosporioides & $0 \mathrm{a}$ & $1 \mathrm{a}$ & $-2 \mathrm{a}$ & $-1 \mathrm{a}$ & $24 \mathrm{a}$ & $17 \mathrm{a}$ & $-4 \mathrm{a}$ \\
Botryodiplodia theobromae & $0 \mathrm{a}$ & $0 \mathrm{a}$ & $6 \mathrm{a}$ & $13 \mathrm{a}$ & $10 \mathrm{a}$ & $1 \mathrm{a}$ & $-1 \mathrm{a}$ \\
Fusarium oxysporum f. sp. niveum & $0 \mathrm{a}$ & $0 \mathrm{a}$ & $-7 \mathrm{a}$ & $20 \mathrm{a}$ & $29 \mathrm{a}$ & $69 \mathrm{a}$ & $73 \mathrm{a}$ \\
Miselium Sclerotium rolfsii & $0 \mathrm{~b}$ & $90 \mathrm{ab}$ & $24 \mathrm{ab}$ & $42 \mathrm{ab}$ & $100 \mathrm{a}$ & $39 \mathrm{ab}$ & $25 \mathrm{ab}$ \\
Sklerotium S. rolfsii & $0 \mathrm{a}$ & $-40 \mathrm{ab}$ & $-20 \mathrm{a}$ & $-31 \mathrm{a}$ & $-113 \mathrm{~b}$ & $-13 \mathrm{a}$ & $-26 \mathrm{a}$ \\
\hline
\end{tabular}

*Angka-angka pada baris yang sama yang diikuti oleh huruf yang sama tidak berbeda nyata berdasarkan uji Tukey pada taraf nyata $1 \%$.

-, tidak terjadi penghambatan relatif pada cendawan model setelah mendapat perlakuan

Tabel 3 Penghambatan relatif (PHR) pertumbuhan cendawan model Microcyclus ulei setelah perlakuan iradiasi UV-C pada jarak dedah 15 dan $30 \mathrm{~cm}$ selama 12 dan 24 jam

\begin{tabular}{lcccc}
\hline \multirow{2}{*}{ Biakan cendawan model } & \multicolumn{4}{c}{ PHR (\%) berdasarkan waktu dan jarak dedah* } \\
\cline { 2 - 5 } & $\begin{array}{c}\text { Jarak dedah } \\
(\mathrm{cm})\end{array}$ & 0 & \multicolumn{3}{c}{ Waktu (jam) } \\
\cline { 2 - 5 } Colletotrichum gloeosporioides & 15 & $0 \mathrm{a}$ & $46 \mathrm{a}$ & $14 \mathrm{a}$ \\
Botryodiplodia theobromae & 30 & $0 \mathrm{a}$ & $10 \mathrm{a}$ & $-13 \mathrm{a}$ \\
& 15 & $0 \mathrm{a}$ & $-1 \mathrm{a}$ & $-2 \mathrm{a}$ \\
Fusarium oxysporum f. sp. & 30 & $0 \mathrm{a}$ & $-1 \mathrm{a}$ & $-3 \mathrm{a}$ \\
niveum & 15 & $0 \mathrm{a}$ & $88 \mathrm{a}$ & $72 \mathrm{a}$ \\
Miselium Sclerotium rolfsii & 30 & $0 \mathrm{a}$ & $66 \mathrm{a}$ & $68 \mathrm{a}$ \\
Sklerotium S. rolfsii & 15 & $0 \mathrm{a}$ & $54 \mathrm{a}$ & $58 \mathrm{a}$ \\
& 30 & $0 \mathrm{a}$ & $38 \mathrm{a}$ & $23 \mathrm{a}$ \\
& 15 & $0 \mathrm{a}$ & $-14 \mathrm{a}$ & $-75 \mathrm{a}$ \\
& 30 & $0 \mathrm{a}$ & $-13 \mathrm{a}$ & $-26 \mathrm{a}$ \\
\hline
\end{tabular}

*Angka-angka pada baris yang sama yang diikuti oleh huruf yang sama tidak berbeda nyata berdasarkan uji

Tukey pada taraf nyata $1 \%$.

-, tidak terjadi penghambatan relatif pada cendawan model setelah mendapat perlakuan 


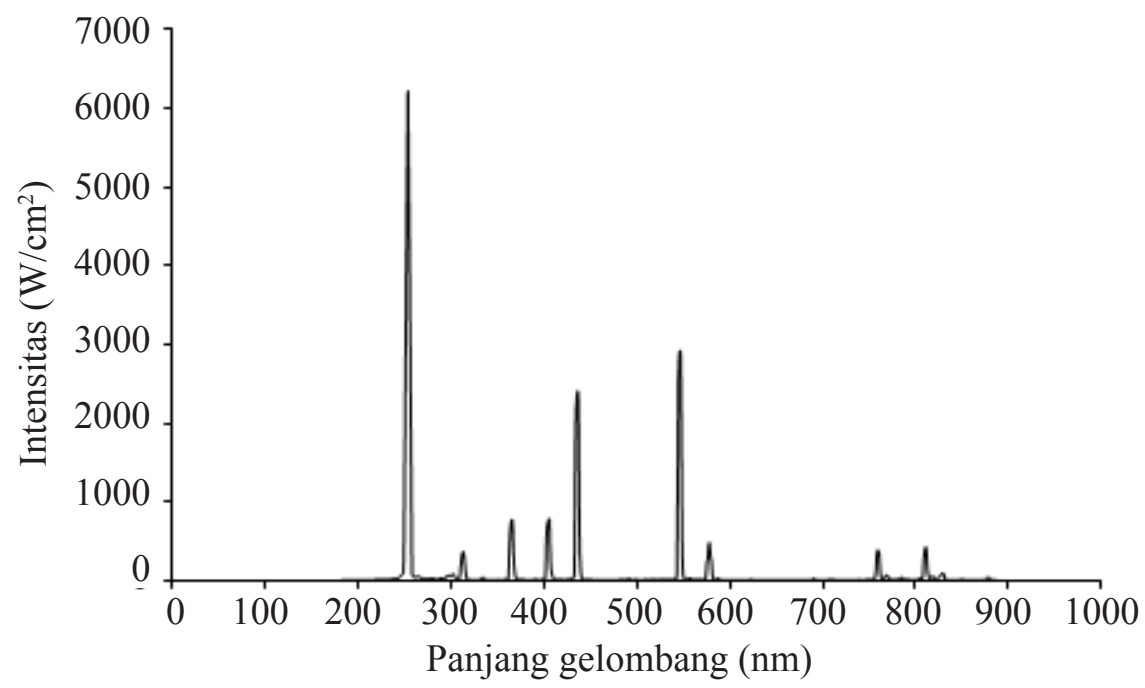

Gambar 1 Panjang gelombang lampu UV-C yang digunakan dalam pengujian.

Tabel 4 Penghambatan relatif (PHR) pertumbuhan cendawan model Microcyclus ulei setelah perlakuan panas kering pada berbagai suhu selama 30 dan 60 menit

\begin{tabular}{|c|c|c|c|c|c|c|c|c|c|c|}
\hline \multirow{3}{*}{ Biakan cendawan model } & \multicolumn{10}{|c|}{ PHR (\%) berdasarkan suhu $\left({ }^{\circ} \mathrm{C}\right)$ dan waktu perlakuan (menit)* } \\
\hline & \multirow{2}{*}{$\mathrm{K}$} & \multicolumn{2}{|c|}{$45^{\circ} \mathrm{C}$} & \multicolumn{2}{|c|}{$50{ }^{\circ} \mathrm{C}$} & $55^{\circ} \mathrm{C}$ & \multicolumn{2}{|c|}{$60{ }^{\circ} \mathrm{C}$} & \multicolumn{2}{|c|}{$65^{\circ} \mathrm{C}$} \\
\hline & & 30 & 60 & 30 & 60 & 30 & 30 & 60 & 30 & 60 \\
\hline Colletotrichum gloeosporioides & $0 \mathrm{c}$ & $0 \mathrm{c}$ & $12 \mathrm{~b}$ & $100 \mathrm{a}$ & $100 \mathrm{a}$ & 100 a $100 \mathrm{a}$ & $100 \mathrm{a}$ & $100 \mathrm{a}$ & $100 \mathrm{a}$ & $100 \mathrm{a}$ \\
\hline Botryodiplodia theobromae & $0 \mathrm{~cd}$ & $-2 \mathrm{~cd}$ & $-6 d$ & $6 \mathrm{c}$ & $51 \mathrm{~b}$ & 100 a $100 \mathrm{a}$ & $100 \mathrm{a}$ & $100 \mathrm{a}$ & $100 \mathrm{a}$ & $100 \mathrm{a}$ \\
\hline $\begin{array}{l}\text { Fusarium oxysporum f. sp. } \\
\text { niveum }\end{array}$ & $0 \mathrm{c}$ & $15 \mathrm{bc}$ & $15 \mathrm{bc}$ & $22 \mathrm{bc}$ & $13 \mathrm{bc}$ & 38 bc 42 b & $100 \mathrm{a}$ & $100 \mathrm{a}$ & $100 \mathrm{a}$ & $100 \mathrm{a}$ \\
\hline Miselium Sclerotium rolfsii & $0 \mathrm{~b}$ & $-2 b$ & $-2 b$ & $100 \mathrm{a}$ & $100 \mathrm{a}$ & 100 a 100 a & $100 \mathrm{a}$ & $100 \mathrm{a}$ & $100 \mathrm{a}$ & $100 \mathrm{a}$ \\
\hline Sklerotium $S$. rolfsii & $0 \mathrm{~b}$ & $-4 b$ & $-2 b$ & $11 \mathrm{~b}$ & $100 \mathrm{a}$ & $100 \mathrm{a} 100 \mathrm{a}$ & $100 \mathrm{a}$ & $100 \mathrm{a}$ & $100 \mathrm{a}$ & 100 \\
\hline
\end{tabular}

rendah dibandingkan dengan suhu aktual pengujian, kecuali pada $F$. oxysporum f. sp. niveum yang menunjukkan $\mathrm{LD}_{99}$ pada suhu di atas $65^{\circ} \mathrm{C}$, selama 30 dan 60 menit. Hasil analisis regresi Program Minitab 16 menunjukkan kematian koloni pada seluruh cendawan model dicapai pada suhu yang jauh lebih tinggi dibandingkan dengan suhu aktual dalam pengujian (Tabel 5). Meskipun demikian, hasil pengujian telah menunjukkan suhu 50, 55, dan $60^{\circ} \mathrm{C}$ selama 30 dan 60 menit efektif mematikan koloni cendawan model. Oleh karena itu, uji lanjut untuk melihat pengaruh perlakuan panas kering dalam mematikan cendawan model pada biji dan bungkil kedelai perlu dilakukan.

\section{Dampak Panas Kering terhadap Daya Tumbuh Cendawan Model pada Biji dan Bungkil Kedelai}

Hasil uji perlakuan panas kering terhadap biji dan bungkil kedelai menunjukkan suhu
$55{ }^{\circ} \mathrm{C}$ selama 30 menit efektif mematikan konidium C. gloeosporioides, B. theobromae, dan $F$. oxysporum f. sp. niveum, tetapi tidak efektif mematikan sklerotium $S$. rolfsii, meskipun sklerotium telah mendapat perlakuan suhu $60^{\circ} \mathrm{C}$ selama 60 menit (Tabel 6). Sklerotium yang diinokulasikan pada biji dan bungkil kedelai hampir seluruhnya dapat membentuk koloni.

\section{Dampak Panas Kering terhadap Kandungan Protein Total pada Biji dan Bungkil Kedelai}

Hasil analisis kandungan protein menunjukkan perlakuan panas kering pada suhu $55{ }^{\circ} \mathrm{C}$ dan $60{ }^{\circ} \mathrm{C}$ relatif tidak mempengaruhi kandungan protein total pada biji dan bungkil kedelai (Gambar 2). Secara umum, kandungan protein total pada biji dan bungkil kedelai uji dengan perlakuan panas kering relatif tidak terlalu berbeda dibandingkan dengan perlakuan kontrol. 
Tabel 5 Penghambatan relatif (PHR) pertumbuhan cendawan model Microcyclus ulei dengan pengamatan aktual, analisis Polo Plus Versi 1.0, dan regresi

\begin{tabular}{|c|c|c|c|c|c|c|c|}
\hline \multirow{2}{*}{$\begin{array}{l}\text { Biakan cendawan model/ } \\
\text { waktu perlakuan (menit) }\end{array}$} & \multicolumn{2}{|c|}{$\begin{array}{l}\text { Pengamatan } \\
\text { aktual }\end{array}$} & \multicolumn{2}{|c|}{$\begin{array}{l}\text { Polo Plus } \\
\text { Versi } 1.0\end{array}$} & \multicolumn{3}{|c|}{ Regresi } \\
\hline & $\begin{array}{c}\text { PHR } \\
(\%)\end{array}$ & $\begin{array}{l}\text { Suhu } \\
\left({ }^{\circ} \mathrm{C}\right)\end{array}$ & $\begin{array}{l}\text { PHR } \\
(\%)\end{array}$ & $\begin{array}{l}\text { Suhu } \\
\left({ }^{\circ} \mathrm{C}\right)\end{array}$ & $\begin{array}{c}\text { PHR } \\
(\%)\end{array}$ & $\begin{array}{l}\text { Suhu } \\
\left({ }^{\circ} \mathrm{C}\right)\end{array}$ & $\mathrm{R}^{2}$ \\
\hline \multicolumn{8}{|c|}{ Colletotrichum gloeosporioides } \\
\hline 30 & 100 & 50 & 99 & 48.5 & 100 & 61 & 0.666 \\
\hline 60 & 100 & 50 & 99 & 47 & 100 & 61 & 0.712 \\
\hline \multicolumn{8}{|l|}{ Botryodiplodia theobromae } \\
\hline 30 & 100 & 55 & 99 & 52.5 & 100 & 62 & 0.779 \\
\hline 60 & 100 & 55 & 99 & 51.5 & 100 & 61.5 & 0.794 \\
\hline \multicolumn{8}{|c|}{ Fusarium oxysporum f. sp. niveum } \\
\hline 30 & 100 & 60 & 99 & $>65$ & 100 & 64 & 0.915 \\
\hline 60 & 100 & 60 & 99 & $>65$ & 100 & 63.5 & 0.910 \\
\hline \multicolumn{8}{|l|}{ Miselium Sclerotium rolfsii } \\
\hline 30 & 100 & 50 & 99 & 48.5 & 100 & 61 & 0.659 \\
\hline 60 & 100 & 50 & 99 & 48.5 & 100 & 61 & 0.659 \\
\hline \multicolumn{8}{|l|}{ Sklerotia $S$. rolfsii } \\
\hline 30 & 100 & 55 & 99 & 52 & 100 & 62 & 0.788 \\
\hline 60 & 100 & 50 & 99 & 48.5 & 100 & 61 & 0.659 \\
\hline
\end{tabular}

Tabel 6 Jumlah koloni cendawan model Microcyclus ulei pada biji dan bungkil kedelai setelah perlakuan panas kering

\begin{tabular}{|c|c|c|c|c|c|c|c|c|c|}
\hline \multicolumn{2}{|c|}{ Perlakuan } & \multicolumn{8}{|c|}{ Jumlah koloni yang terbentuk* } \\
\hline \multirow{2}{*}{$\begin{array}{l}\text { Suhu } \\
\left({ }^{\circ} \mathrm{C}\right)\end{array}$} & \multirow{2}{*}{$\begin{array}{l}\text { Waktu } \\
\text { (menit) }\end{array}$} & \multicolumn{2}{|c|}{$\begin{array}{l}\text { Botryodiplodia } \\
\text { theobromae }\end{array}$} & \multicolumn{2}{|c|}{$\begin{array}{l}\text { Colletotrichum } \\
\text { gloeosporioides }\end{array}$} & \multicolumn{2}{|c|}{$\begin{array}{l}\text { Fusarium oxysporum } \\
\text { f. sp. niveum }\end{array}$} & \multicolumn{2}{|c|}{$\begin{array}{l}\text { Sclerotium } \\
\quad \text { rolfsii }\end{array}$} \\
\hline & & Biji & Bungkil & Biji & Bungkil & Biji & Bungkil & $\overline{\mathrm{Biji}}$ & Bungkil \\
\hline \multirow{3}{*}{$\begin{array}{l}\text { Kontrol } \\
50\end{array}$} & & 0.8 & 12.8 & 2 & 21.6 & 8.2 & 62.6 & 4 & 4 \\
\hline & 30 & 0 & 1.8 & 0 & 0 & 0.2 & 20.6 & 4 & 4 \\
\hline & 60 & 0 & 0.6 & 0 & 0 & 0 & 0.4 & 4 & 4 \\
\hline \multirow[t]{2}{*}{55} & 30 & 0 & 0 & 0 & 0 & 0 & 0 & 4 & 4 \\
\hline & 60 & 0 & 0 & 0 & 0 & 0 & 0 & 4 & 4 \\
\hline \multirow[t]{2}{*}{60} & 30 & 0 & 0 & 0 & 0 & 0 & 0 & 4 & 3.4 \\
\hline & 60 & 0 & 0 & 0 & 0 & 0 & 0 & 4 & 4 \\
\hline
\end{tabular}

*Rerata dari 5 ulangan.
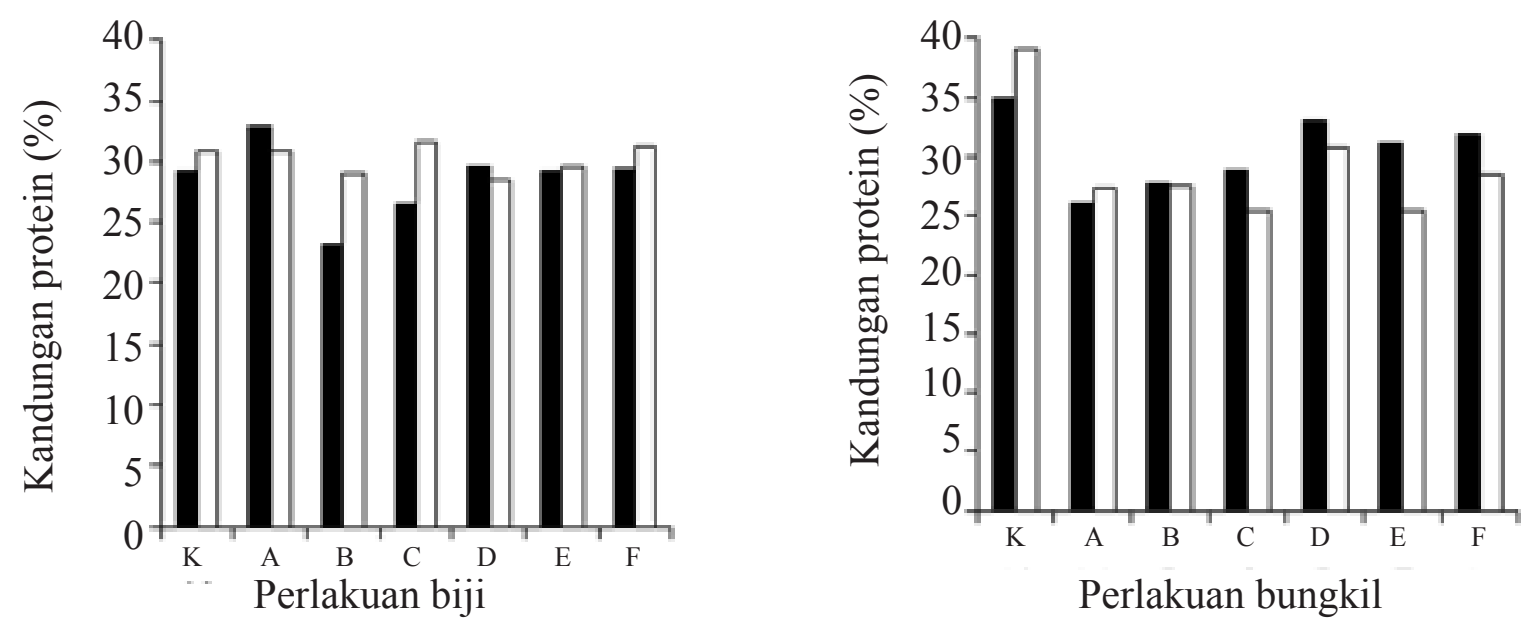

Gambar 2 Pengaruh perlakuan panas kering dan inokulasi Colletotrichum gloeosporioides terhadap kandungan protein biji dan bungkil kedelai. $\square$, tanpa inokulasi; $\mathbf{\square}$, dengan inokulasi; $\mathrm{K}$, Kontrol; A, $50{ }^{\circ} \mathrm{C} 30$ menit; B, $50{ }^{\circ} \mathrm{C} 60$ menit; C, $55{ }^{\circ} \mathrm{C} 30$ menit; D, $55{ }^{\circ} \mathrm{C} 60$ menit; E, $60{ }^{\circ} \mathrm{C} 30$ menit; F, $60{ }^{\circ} \mathrm{C} 60$ menit. 


\section{PEMBAHASAN}

Beberapa peneliti melaporkan bahwa iradiasi UV-C efektif mematikan spora cendawan yang ditumbuhkan pada medium biakan atau secara langsung pada suspensi konidium M. ulei hanya dengan waktu dedah yang relatif singkat dan jarak dedah yang relatif pendek (Juri et al. 1997; Begum et al. 2009). Namun, dalam percobaan ini iradiasi UV-C tidak efektif mematikan cendawan model uji. Berdasarkan pemeriksaan lampu UV-C yang digunakan, ternyata lampu tersebut juga memancarkan panjang gelombang NUV yang dapat menstimulasi sporulasi beberapa cendawan. Hal ini yang memungkinkan cendawan model masih tetap tumbuh, meskipun telah mendapat perlakuan iradiasi UV-C pada jarak $15 \mathrm{~cm}$ selama 24 jam. Atas dasar tersebut, dapat disimpulkan bahwa lampu UV-C yang digunakan tidak memenuhi persyaratan panjang gelombang UV-C yang dapat mematikan cendawan model. Studi lanjut dengan lampu UV-C yang hanya memiliki panjang gelombang 200-280 nm perlu dilakukan untuk mendapatkan informasi yang akurat.

Perlakuan panas kering $55{ }^{\circ} \mathrm{C}$ selama 30 menit dapat menghambat pertumbuhan atau mematikan cendawan patogen uji, kecuali $S$. rolfsii. Cendawan $S$. rolfsii yang tetap berkecambah meskipun telah diberi perlakuan panas hingga mencapai $60{ }^{\circ} \mathrm{C}$ selama 60 menit kemungkinan besar karena mampu membentuk sklerotium. Sklerotium merupakan struktur bertahan yang dilindungi oleh dinding sel yang masif dan tebal dan tidak dapat ditembus oleh fungisida sehingga kemungkinan besar tetap dapat melindungi sel atau jaringan sel dari panas $60{ }^{\circ} \mathrm{C}$ selama 60 menit. Namun, dengan adanya hasil regresi pengujian perlakuan panas kering pada medium PDA diketahui suhu $61{ }^{\circ} \mathrm{C}$ selama 60 menit atau $62{ }^{\circ} \mathrm{C}$ selama 30 menit dapat mematikan sklerotium $S$. rolfsii. Dengan demikian, untuk lebih meminimalkan risiko masuknya $M$. ulei melalui produk impor nonkaret yang berasal dari negara endemis SALB, direkomendasikan perlakuan panas kering pada suhu minimal
$62{ }^{\circ} \mathrm{C}$ selama 60 menit sebagai perlakuan karantina tumbuhan, tetapi produk yang akan diberi perlakuan harus dalam jumlah kecil.

Perlakuan panas kering yang efektif mematikan cendawan model pada biji dan bungkil kedelai dalam pengujian ini relatif tidak mempengaruhi kandungan protein total pada biji dan bungkil kedelai. Berdasarkan hasil uji protein diketahui kandungan protein total pada biji kedelai asal Amerika Serikat yang digunakan dalam pengujian ini lebih rendah daripada biji kedelai impor pada umumnya (Ginting et al. 2009). Selain itu, kandungan protein total pada bungkil kedelai asal Brazil juga lebih rendah dibandingkan dengan kandungan protein bungkil berdasarkan SNI 01-4227-1996. Kandungan protein total yang rendah disebabkan oleh masa penyimpanan yang terlalu lama sejak panen hingga dipasarkan di Indonesia dan pengaruh proses produksi maupun penanganan sejak di negara asal.

\section{UCAPAN TERIMA KASIH}

Ucapan terima kasih disampaikan kepada Badan Karantina Pertanian, Balai Uji Terap Teknik dan Metoda Karantina Pertanian, dan Balai Karantina Pertanian Kelas II Cilegon atas dukungan teknis yang diberikan selama penelitian ini.

\section{DAFTAR PUSTAKA}

Begum M, Hocking AD, Miskelly DI. 2009. Inactivation of food spoilage fungi by ultra violet (UVC) irradiation [abstrak]. Int J Food Microbiol. 129(1):4-77. DOI: http://dx.doi.org/10.1016/j.ijfoodmicro. 2008.11.020.

Chee KH. 1976. Factors affecting discharge, germinating and viability of spores of Microcyclus ulei [abstrak]. Brit Mycol Soc. 66(3):499-504. DOI: http://dx.doi. org/10.1016/S0007-1536(76)80221-5.

[Deptan] Departemen Pertanian. 1989. Keputusan Menteri Pertanian Nomor 861/ Kpts/LB.720/12/1989 tentang Pencegahan 
Masuknya Penyakit Hawar Daun Hevea Amerika Selatan ke Dalam Wilayah Negara Republik Indonesia. Jakarta (ID): Deptan.

Edathil TT. 1986. South American leaf blight: a potential threat to the natural rubber industry in Asia and Africa. Trop Pest Manage. 32(4):296-303. DOI: http://dx. doi.org/10.1080/09670878609371083.

[FAO] Food and Agriculture Organization of the United Nations. 2007. Report of the $25^{\text {th }}$ session of the Asia and Pacific Plant Protection Commission. Bangkok (TH): FAO Regional Office for Asia and the Pacific.

Ginting E, Antarlina SS, Widowati S. 2009. Varietas unggul kedelai untuk bahan baku industri pangan. J Litbang Pertanian. 28(3):79-87.

Hashim I. 2007. South American leaf blight (Microcyclus ulei) of hevea rubber. Di dalam: CFC-Michelin-IRRDB International
Training and Technology Transfer Workshop on Enhanched Management Control of South American Leaf Blight; 200726 Nov-2 Des; Bahia (BR): International Rubber Research and Development Board. hlm 21-43.

Kaiser C, Van der Merwe R, Bekker TF, Labuschagne. 2005. In-vitro inhibition of mycelial growth of several phytopathogenic fungi, including Phytophthora cinnamomi by soluble silicon. South African Avocado Growers Association Yearbook. 28:70-74.

[Kementan] Kementerian Pertanian. 2011. Peraturan Menteri Pertanian Nomor 93/ Permentan/OT.140/12/201 tentang Jenis Organisme Pengganggu Tumbuhan Karantina. Jakarta (ID): Kementan.

Juri ML, Bahari I, Lieberaei R, Omar M. 1997. The effect of X-rays, UV, temperature and sterilant on the survival of fungal conidia Microcyclus ulei, a blight of hevea rubber. Trop Sci. 37(2):92-98. 